\title{
Batrachochytrium dendrobatidis infection of amphibians in the Doñana National Park, Spain
}

\author{
Judit Hidalgo-Vila ${ }^{1, *}$, Carmen Díaz-Paniagua ${ }^{2}$, Marc A. Marchand ${ }^{2}$, \\ Andrew A. Cunningham ${ }^{1}$ \\ ${ }^{1}$ Institute of Zoology, Regent's Park, London NW1 4RY, UK \\ ${ }^{2}$ Doñana Biological Station-(EBD-CSIC), Americo Vespucio s/n, 41080 Seville, Spain
}

\begin{abstract}
Amphibian chytridiomycosis, caused by infection with the non-hyphal, zoosporic chytrid fungus Batrachochytrium dendrobatidis $(B d)$, is an emerging infectious disease recognised as a cause of recent amphibian population declines and extinctions worldwide. The Doñana National Park (DNP) is located in southwestern Spain, a country with widespread Bd infection. This protected area has a great diversity of aquatic habitats that constitute important breeding habitats for 11 native amphibian species. We sampled 625 amphibians in December 2007 and February to March 2008, months that correspond to the early and intermediate breeding seasons for amphibians, respectively. We found 7 of 9 sampled species to be infected with $B d$ and found differences in prevalence between sampling periods. Although some amphibians tested had higher intensities of infection than others, all animals sampled were apparently healthy and, so far, there has been no evidence of either unusually high rates of mortality or amphibian population declines in the DNP.
\end{abstract}

KEY WORDS: Breeding habitat · Chytridiomycosis · Chytrid · Emerging infectious disease . Seasonality

Resale or republication not permitted without written consent of the publisher

\section{INTRODUCTION}

Amphibian chytridiomycosis, caused by the nonhyphal, zoosporic chytrid fungus Batrachochytrium dendrobatidis $(B d)$, (Longcore et al. 1999) is a highly virulent, recently emerged infectious disease that has caused amphibian population declines and extinctions globally (Berger et al. 1998, Daszak et al. 1999, 2003, Bosch et al. 2001, Stuart et al. 2004, Bosch \& Martínez-Solano 2006, Lips et al. 2006). This disease has been described as the most important emerging disease of vertebrates and the proximate cause of rapid population declines of more than 200 amphibian species (Skerratt et al. 2007).

$B d$ infects only the keratinized tissues of amphibians (Berger et al. 1999). In anurans, these are found only in the epidermis of post-metamorphic animals and in the mouthparts of larvae (Marantelli et al. 2004). Clin- ical signs of infection often are inapparent until the animal is close to death, but infected metamorphosed animals may exhibit excessive epidermal sloughing; i.e. epidermal hyperplasia and hyperkeratosis that are evident on the microscopic examination of infected skin (Berger et al. 1998, 1999, Nichols et al. 2001). Death is thought to be due to disruption of water and electrolyte exchange through the skin, which leads to cardiac arrest (Voyles et al. 2009). Larval anurans can be asymptomatic carriers of infection, although loss of infected mouthparts can lead to death or reduced fitness and may include increased time to reach metamorphosis and reduced survival rates of post-metamorphic animals (Garner et al. 2009).

$B d$ is extraordinary because it has such low host specificity within the Amphibia and, among amphibian species exposed to $B d$, many populations have declined, sometimes to extinction (Berger et al. 1998, 
Bosch et al. 2001, 2007, Bosch \& Martínez-Solano 2006, Lips et al. 2006, Bielby et al. 2009), while others have been apparently unaffected (McDonald \& Alford 1999, Kriger \& Hero 2006a). A complex interaction of host species, animal behaviour, pathogen strain and environmental (including humidity and temperature) factors appear to influence the outcome of $B d$ infection (Berger et al. 2004, Burrowes et al. 2004, Rollins-Smith et al. 2006, Kriger \& Hero 2006b, 2007, Longcore et al. 2007, Fisher et al. 2009a,b). Furthermore, recent studies have shown protective effects of antimicrobial skin peptides and of certain components of the commensal skin microbial flora that may explain differential mortality within and amongst amphibian populations and species (RollinsSmith et al. 2002, 2006, Harris et al. 2006, Woodhams et al. 2006a,b, 2007a,b,c).

Although $B d$ infection of amphibians has been reported from across much of western Europe (e.g. Garner et al. 2005, Duffus \& Cunningham 2010), European amphibian declines caused by $B d$ have been reported primarily in Spain (e.g. Bosch et al.

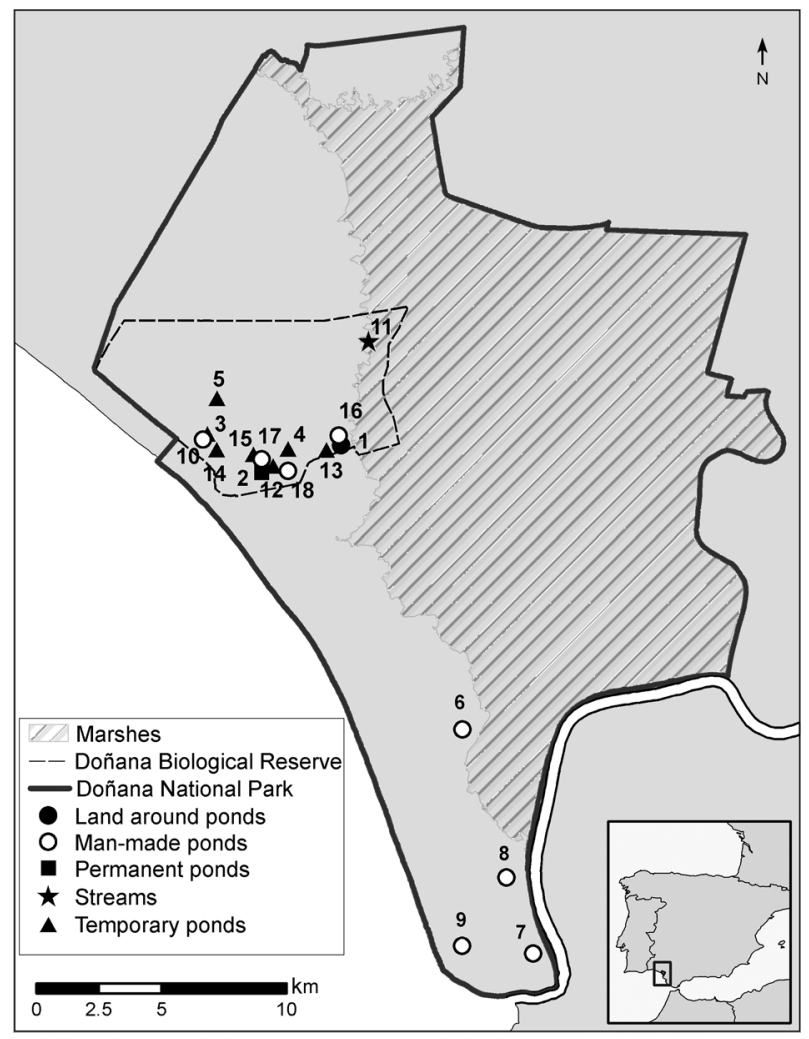

Fig. 1. Batrachochytrium dendrobatidis. Sampling locations in the Doñana National Park to detect the presence of $B d$ infection in amphibians. The Doñana Biological Reserve is outlined with a dashed line. Inset shows location of the park in southern Spain (see 'Introduction' for latitude/longitude)
2001，2007, Bosch \& Martínez-Solano 2006). The Doñana National Park (DNP) is an important protected area covering 54251 ha located in southwestern Spain (centre coordinates: $37^{\circ} 00^{\prime} \mathrm{N}, 6^{\circ} 38^{\prime} \mathrm{W}$ ). Within the boundaries of the national park, a territory designated as the Doñana Biological Reserve constitutes the core of the park (Fig. 1). The DNP is one of the largest and most important wetlands in Europe and the largest wetland in Spain as designated by The Ramsar Convention or 'Convention on Wetlands of International Importance' (www.ramsar.org/). The DNP includes a great variety of aquatic systems: marshes, 2 large permanent ponds and a large network of Mediterranean temporary ponds of natural origin, of which more than 3000 of these water bodies occur in very wet years (Díaz-Paniagua et al. 2010). In addition, a large number of human-made permanent ponds are scattered throughout the DNP to provide water for cattle or wild mammals during the dry season. This great diversity of water bodies has made the DNP an area with a wide availability of breeding sites for 11 native amphibian species: Bufo bufo, $B$. calamita, Pelobates cultripes, Pelophylax perezi, Hyla meridionalis, Pleurodeles waltl, Pelodytes ibericus, Discoglossus galganoi, Triturus pygmaeus, Lissotriton boscai and Alytes cisternasii, the last 5 of which are endemic to the Iberian Peninsula (DíazPaniagua et al. 2005). In the DNP, amphibian reproduction is segregated through the annual period of pond inundation. Some species may start breeding in autumn (early breeders), others start breeding in winter (intermediate breeders) and one species delays breeding to late spring (late breeder) (DíazPaniagua 1988).

The aim of this study was to carry out the first survey for $B d$ infection in this protected area by sampling during different seasons in order to take into account the influence of the temporal segregation of the reproduction and the aquatic phase of amphibians described in this area.

\section{MATERIALS AND METHODS}

Amphibians were captured and sampled in the DNP during 2 periods: (1) from 10 to 22 December 2007 and (2) from 19 to 20 February and 3 to 5 March 2008, which correspond to the early and intermediate breeding seasons, respectively, described for amphibians in this area (Díaz-Paniagua 1988).

In December, we caught and swabbed 450 amphibians (437 adults and 13 tadpoles) (see Table 1, Fig. 1). Of this total, 300 animals were captured from 
16 water bodies ( 1 permanent large pond, 8 permanent human-made ponds and 7 temporary ponds), and 150 amphibians were captured on land. During the second sampling period, 175 amphibians (172 adults and 3 tadpoles) were caught and sampled from 8 water bodies (4 temporary ponds and 3 human-made permanent ponds, all of which had been sampled during the early breeding season, and 1 intermittent stream) (see Table 1, Fig. 1). Each amphibian species recorded in the DNP during the first sampling period, apart from Alytes cisternasii and Pelodytes ibericus, was sampled in the second, although some were caught only in small numbers (see Table 2). Bufo bufo was not captured during the second sampling period.

Amphibians were caught by hand or by net. To prevent cross-contamination between animals, a new pair of disposable Sempermed ${ }^{\circledR}$ nitrile gloves (DISPOLAB) was worn for the capture and handling of animals of each site and the net was disinfected with Virkon ${ }^{\circledR}$ (Antec International) and rinsed with fresh water between each capture site. Each animal caught was immediately sampled noninvasively with a sterile rayon-tipped swab (MW100-100, Medical Wire \& Equipment). The mouthparts of larval anurans and the ventral pelvic skin and skin of the plantar area of the feet (known predilection sites for $B d$ infection) of metamorphosed amphibians were swabbed, as described by Hyatt et al. (2007).

Nucleic acid was extracted from the skin swabs following the protocol of Boyle et al. (2004). Briefly, 30 to $40 \mathrm{mg}$ zirconium/silica beads measuring $0.5 \mathrm{~mm}$ in diameter (Biospec Products) and $60 \mu$ PrepMan Ultra (Applied Biosystems) were added to the cotton tip of each swab. The swab was then homogenised for $45 \mathrm{~s}$ in a Mini Beadbeater 8 (Biospec Products) and centrifuged twice for $30 \mathrm{~s}$ at $13000 \times \mathrm{g}$. Subsequently, samples were boiled for $10 \mathrm{~min}$, cooled for $2 \mathrm{~min}$ and centrifuged at $13000 \times g$ for $3 \mathrm{~min}$. A $40 \mu \mathrm{l}$ volume of supernatant of each sample was removed and diluted $(1: 10)$ in distilled water. Dilutions were analysed by means of the real-time Taqman PCR assay of Boyle et al. (2004) with the 7300 Sequence Detection System (v. 1.4.0, Applied Biosystems). The ITS1 and 5.8S primers (Eurofins MWG Operon) and the TaqMan MGB2 probe were added to the samples in 96-well plates. Each sample was tested in duplicate. A negative control and standards of $0.1,1,10$ and 100 zoospore equivalents were included in each realtime PCR plate.

A sample was considered to be positive for $B d$ if at least 0.1 zoospore equivalent was detected in each duplicate well. Quantification of $B d$ zoospores from infected individuals is presented as the mean value obtained from the 2 replicates.

Infection prevalence during each sampling period was calculated by dividing the number of positive individuals for $B d$ by the total number of amphibians sampled. This assumes that all amphibians throughout the DNP are in an epidemiologically contiguous population, each amphibian tested (regardless of life stage or species) was equally susceptible to $B d$ infection, if exposed, and infection was equally detectable, if present, across species and life stages.

\section{RESULTS}

There was a seasonal effect, and no infection was detected in any of the 450 amphibians (including the 300 captured in water) sampled during the earlier sampling period (December), but there was an overall $34 \%$ prevalence (60 of 175) of $B d$ detected in the second sampling period, which corresponded with the intermediate breeding season (February to March) (Table 1). All amphibians positive for $B d$ were captured in 4 of the 8 water bodies sampled during this period, 1 temporary pond and 3 humanmade permanent ponds (Table 1, Fig. 1).

Of the 8 species sampled during the second period, all except Bufo calamita were positive for $B d$ infection (Table 2). However, the numbers of each species caught were too small to calculate differences in the prevalence of infection among species (Table 2). Despite this, the urodele species tested (Triturus pygmaeus, Lissotriton boscai and Pleurodeles waltl) registered the highest prevalences of infection (around $60 \%$ ); however, the intensities of infection in these species were very low in comparison with the levels of infection detected in Hyla meridionalis, the species with the highest intensity of infection (Table 2).

$B d$ was detected in most species at the positive sites, regardless of sample size (Table 3). Except for Pelobates cultripes, all infected amphibian species were captured in both a temporary pond and in human-made permanent ponds, although the highest diversity of amphibians was found in the temporary pond (Table 3 ).

\section{DISCUSSION}

We found $B d$-infected amphibians in the DNP, where at least 7 of the 11 amphibian species were infected, including 3 species endemic to the Iberian Peninsula (Discoglossus galganoi, Triturus pygmaeus 
Table 1. Batrachochytrium dendrobatidis. Prevalence of $B d$ infection as a function of the time period and site types. L: land (around temporary ponds) ${ }_{i}$ P: permanent large pond; T: temporary pond; S: stream; HM: human-made permanent pond. EBS: early breeding season; IBS: intermediate

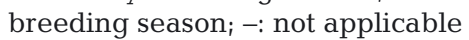

\begin{tabular}{|c|c|c|c|c|c|}
\hline \multirow{2}{*}{$\begin{array}{l}\text { Site } \\
\text { ID }\end{array}$} & \multirow{2}{*}{$\begin{array}{l}\text { Site } \\
\text { type }\end{array}$} & \multicolumn{2}{|c|}{$\longrightarrow$ Dec $($ EBS $)-$} & \multicolumn{2}{|c|}{ Feb-Mar (IBS) } \\
\hline & & $\begin{array}{c}\text { No. } \\
\text { sampled }\end{array}$ & $\begin{array}{l}\text { No. } B d- \\
\text { positive }\end{array}$ & $\begin{array}{c}\text { No. } \\
\text { sampled }\end{array}$ & $\begin{array}{l}\text { No. } B d- \\
\text { positive }\end{array}$ \\
\hline 1 & $\mathrm{~L}$ & 150 & 0 & 0 & - \\
\hline 2 & P & 4 & 0 & 0 & - \\
\hline 3 & $\mathrm{~T}$ & 11 & 0 & 0 & - \\
\hline 4 & $\mathrm{~T}$ & 37 & 0 & 0 & - \\
\hline 5 & $\mathrm{~T}$ & 5 & 0 & 0 & - \\
\hline 6 & HM & 30 & 0 & 0 & - \\
\hline 7 & HM & 1 & 0 & 0 & - \\
\hline 8 & HM & 1 & 0 & 0 & - \\
\hline 9 & HM & 19 & 0 & 0 & - \\
\hline 10 & $\mathrm{HM}$ & 13 & 0 & 0 & - \\
\hline 11 & $\mathrm{~S}$ & 0 & - & 28 & 0 \\
\hline 12 & $\mathrm{~T}$ & 54 & 0 & 3 & 0 \\
\hline 13 & $\mathrm{~T}$ & 15 & 0 & 39 & 0 \\
\hline 14 & $\mathrm{~T}$ & 11 & 0 & 2 & 0 \\
\hline 15 & $\mathrm{~T}$ & 36 & 0 & 48 & $33(68.7 \%)$ \\
\hline 16 & HM & 10 & 0 & 9 & $3(33.3 \%)$ \\
\hline 17 & HM & 28 & 0 & 13 & $5(38.5 \%)$ \\
\hline 18 & HM & 25 & 0 & 33 & $19(57.6 \%)$ \\
\hline Total & & 450 & 0 & 175 & 60 \\
\hline
\end{tabular}

and Lissotriton boscai). We did not detect infection in 2 species, Bufo bufo and B. calamita, which are those species with the most terrestrial habits and the shortest aquatic phase in this region. However, only a single $B$. bufo swab was tested, so no conclusions can be drawn for this species.

Table 2. Batrachochytrium dendrobatidis. Prevalance and intensity of $B d$ infection as a function of the amphibian species analysed during the second sampling period. (zoospore equivalent counts = geometric mean number of $B d$ zoospores detected on each infected amphibian species, 1:10 dilution factor). EBS: early breeding season; IBS: intermediate breeding season; -: not applicable

\begin{tabular}{|c|c|c|c|c|c|}
\hline \multirow[t]{2}{*}{ Species } & \multicolumn{2}{|c|}{ Dec (EBS) } & \multicolumn{2}{|c|}{ —Feb-Mar (IBS) — } & \multirow{2}{*}{$\begin{array}{l}\text { Zoospore } \\
\text { equivalent } \\
\text { counts }\end{array}$} \\
\hline & $\begin{array}{c}\text { No. } \\
\text { sampled }\end{array}$ & $\begin{array}{l}\text { No. } B d- \\
\text { positive }\end{array}$ & $\begin{array}{c}\text { No. } \\
\text { sampled }\end{array}$ & $\begin{array}{l}\text { No. } B d- \\
\text { positive }\end{array}$ & \\
\hline Triturus pygmaeus & 96 & 0 & 54 & $37(68.5 \%)$ & 1.70 \\
\hline Lissotriton boscai & 55 & 0 & 3 & $2(66.7 \%)$ & 0.17 \\
\hline Pleurodeles waltı & 51 & 0 & 11 & $7(63.7 \%)$ & 1.23 \\
\hline Hyla meridionalis & 99 & 0 & 15 & $7(46.7 \%)$ & 363.71 \\
\hline Pelophylax perezi & 41 & 0 & 5 & $2(40.0 \%)$ & 0.81 \\
\hline $\begin{array}{l}\text { Discoglossus } \\
\text { galganoi }\end{array}$ & 4 & 0 & 23 & $4(17.4 \%)$ & 40.29 \\
\hline Pelobates cultripes & 69 & 0 & 24 & $1(4.2 \%)$ & 1.87 \\
\hline Bufo bufo & 1 & 0 & 0 & - & - \\
\hline Bufo calamita & 34 & 0 & 40 & 0 & - \\
\hline
\end{tabular}

Owing to the physiological limitations of $B d$, which cannot survive desiccation (Johnson et al. 2003), it is likely that amphibians in the permanent ponds act as reservoirs for the fungus when temporary ponds dry out during the summer season. In Australia, Kriger \& Hero (2007) found that frogs breeding in permanent water bodies were significantly more likely to be infected with $B d$ than those breeding in ephemeral or terrestrial habitats. This could also be the case in the DNP, where we found that all 3 of the permanent ponds and only 1 of 4 temporary ponds contained $B d$ positive amphibians during the intermediate breeding season. This temporary pond in which amphibians tested positive (Site 15) is a large pond that usually dries out in summer, but in very wet years, as in the year previous to our study, a small pool of water may remain until the next wet season. Tadpoles in these remnant small pools may overwinter and act as reservoir hosts for $B d$, as has been previously reported in Australia for $B d$-positive tadpoles of Mixophyes shevilli and Litoria nannotis (Woodhams \& Alford 2005). Fewer than 5 individuals were sampled from each of the $2 B d$-negative temporary ponds during the second sampling period, so it is possible that infection was missed in these other temporary water bodies.

Apart from 2 permanent ponds, human-made ponds are scattered throughout the DNP to supply water for cattle and wild mammals (Díaz-Paniagua et al. 2010), and these could also be $B d$ reservoirs. However, owing to the small size of these ponds during the summer, they probably reach temperatures close to or above lethal values for $B d$ (Johnson et al. 2003, Berger et al. 2004).

We did not detect $B d$ infection during the first sampling period, but did detect it in the second period, when most of the species had already started their annual reproduction and adults had spent weeks or months (depending on the species) in the ponds. Owing to the aquatic requirements of $B d$ (Berger et al. 1998, Johnson et al. 2003), it would be expected that prevalence of infection would increase over the period that amphibians are in the ponds and, hence, become easier to detect with the sample sizes tested in the present study. This is supported by the finding that $B d$ infection was more likely to be detected in those species for which the adults 
Table 3. Batrachochytrium dendrobatidis. Presence of $B d$ infection as a function of the sampled species in each of the 4 sites in which amphibians tested positive. EBS: early breeding season; IBS: intermediate breeding season; - : not applicable

\begin{tabular}{|c|c|c|c|c|}
\hline \multirow[t]{2}{*}{ Species } & \multicolumn{2}{|c|}{$\longrightarrow$ Dec $(\mathrm{EBS})-$} & \multicolumn{2}{|c|}{-Feb-Mar (IBS)— } \\
\hline & $\begin{array}{c}\text { No. } \\
\text { sampled }\end{array}$ & $\begin{array}{l}\text { No. } B d- \\
\text { positive }\end{array}$ & $\begin{array}{c}\text { No. } \\
\text { sampled }\end{array}$ & $\begin{array}{l}\text { No. } B d- \\
\text { positive }\end{array}$ \\
\hline \multicolumn{5}{|l|}{ Site 15 (temporary pond) } \\
\hline Discoglossus galganoi & 0 & - & 2 & 1 \\
\hline Hyla meridionalis & 1 & 0 & 6 & 5 \\
\hline Lissotriton boscai & 1 & 0 & 2 & 1 \\
\hline Pelobates cultripes (adults) & 0 & - & 1 & 0 \\
\hline Pelobates cultripes (tadpoles) & 9 & 0 & 3 & 1 \\
\hline Pleurodeles waltl (adults) & 2 & 0 & 9 & 5 \\
\hline Pleurodeles waltl (tadpoles) & 4 & 0 & 0 & - \\
\hline Pelophylax perezi & 0 & - & 3 & 2 \\
\hline Triturus pygmaeus & 19 & 0 & 22 & 18 \\
\hline \multicolumn{5}{|c|}{ Site 16 (human-made permanent pond) } \\
\hline Discoglossus galganoi & 0 & - & 9 & 3 \\
\hline Lissotriton boscai & 9 & 0 & 0 & - \\
\hline Triturus pygmaeus & 1 & 0 & 0 & - \\
\hline \multicolumn{5}{|c|}{ Site 17 (human-made permanent pond) } \\
\hline Hyla meridionalis & 1 & 0 & 7 & 1 \\
\hline Lissotriton boscai & 2 & 0 & 0 & - \\
\hline Pleurodeles waltl & 4 & 0 & 0 & - \\
\hline Pelophylax perezi & 1 & 0 & 1 & 0 \\
\hline Triturus pygmaeus & 20 & 0 & 5 & 4 \\
\hline \multicolumn{5}{|c|}{ Site 18 (human-made permanent pond) } \\
\hline Hyla meridionalis & 0 & - & 2 & 1 \\
\hline Lissotriton boscai & 1 & 0 & 1 & 1 \\
\hline Pleurodeles waltl & 2 & 0 & 2 & 2 \\
\hline Pelophylax perezi & 0 & - & 1 & 0 \\
\hline Triturus pygmaeus & 22 & 0 & 27 & 15 \\
\hline
\end{tabular}

Despite the apparently high overall prevalence $(34 \%)$ of infection detected in the intermediate breeding season, no evidence of disease, unusually high mortality or population declines has been detected in the DNP. In fact, amphibians have been extensively studied in this area over the last 2 decades and no evidence of adult or larval mortalities has been detected. Although chytridiomycosis has caused mass mortalities, and even extinctions, of amphibian species globally, the DNP might be an example of a locality in which $B d$ is present without an apparent pathogenic effect on amphibian populations. Further work, however, is required to determine if this is truly the case or if effects on the DNP amphibians are cryptic, such as decreased fecundity or longevity, rather than exhibited as overt mortality events. Alternatively, $B d$ might be a recent introduction to the DNP, although the widespread occurrence detected during the second sampling period would suggest otherwise.

Some bacterial species that live on the epidermis of amphibians produce antibiotics that inhibit the growth of are known to have a longer aquatic phase during the breeding season: the 3 urodeles (Triturus pygmaeus, Lissotriton boscai and Pleurodeles waltl) and the anurans (Hyla meridionalis and Pelophylax perezi) (Díaz-Paniagua et al. 2005). In contrast, detection of infection was low or zero in the species that have a short aquatic adult breeding phase, Pelobates cultripes and Bufo calamita (DíazPaniagua et al. 2005). Adult amphibians might be infected at a low prevalence (and possibly also a low infection intensity) outside the breeding season, and prevalence (or infection intensity) may be too low for reliable detection when sample sizes are small. In this study, the largest numbers of amphibians sampled from a single water body during the first visit (early breeding season) were 28 and 37 (Sites 17 and 4, respectively). A sample size of 30 animals would provide a $99 \%$ chance of detecting a $15 \%$ prevalence, but only a $26 \%$ chance of detecting a $1 \%$ prevalence; thus, it is also possible that a low prevalence of infection was present, but not detected, at that time.
$B d$ (Harris et al. 2006, Woodhams et al. 2007c) as do some antimicrobial peptides produced by granular glands in amphibian skin (Rollins-Smith et al. 2002, 2006, Woodhams et al. 2006a,b, 2007a,b). The presence of such antifungal bacteria and skin peptides has been reported to explain differences in the occurrence of disease amongst $B d$-infected amphibian species and populations (Woodhams et al. 2006b, $2007 \mathrm{a}, \mathrm{b})$. Differences in host response to $B d$ infection also could be related to differences in virulence among $B d$ strains, as has been recently proposed by Fisher et al. (2009b).

In summary, we detected $B d$ infection in 7 of 9 amphibian species tested in the DNP. The amphibian populations of the DNP have been closely studied over many years, but no evidence of unusually high levels of mortality or of population declines has been detected. This may be because the species complement the $B d$ strain present, or the environmental characteristics of the DNP do not favour a negative impact of $B d$ infection on the extant amphibian population. Although this has been the case so far, we 
recommend continued monitoring of both amphibian populations and their $B d$ status in the DNP in order to further investigate this host-parasite relationship and determine if any ecological factors, such as prolonged wet periods or periods of drought, may alter the current situation.

Acknowledgements. We thank X. Ruíz, N. Pérez-Santigosa, I. Gómez-Mestre, F. J. Jiménez, G. Gueso, E. Albert and J. Bosch for their field assistance, and M. Perkins for his technical support. Thanks also to T. W. J. Garner for comments on study design and for stimulating discussions. B. Arrizabalaga and R. Rodríguez gave us all the necessary logistical support. J.H.V. was financed by the Spanish Ministry of Education and Science (EX2006-1619). This study was supported by ICTS-Doñana Biological Reserve and was funded by the Spanish Ministry of Science and Innovation (ICTS2006-09) and the Institute of Zoology, Zoological Society of London.

\section{LITERATURE CITED}

Berger L, Speare R, Daszak P, Green DE and others (1998) Chytridiomycosis causes amphibian mortality associated with population declines in the rain forests of Australia and Central America. Proc Natl Acad Sci USA 95: 9031-9036

Berger L, Speare R, Hyatt AD (1999) Chytrid fungi and amphibian declines: overview, implications and future direction. In: Campbell A (ed) Declines and disappearances of Australian frogs. Environment Australia, Canberra, p 23-33

Berger L, Speare R, Hines HB, Marantelli G and others (2004) Effect of season and temperature on mortality in amphibians due to chytridiomycosis. Aust Vet J 82:31-36

Bielby J, Bovero S, Sotgiu G, Tessa G and others (2009) Fatal chytridiomycosis in the Tyrrhenian painted frog. EcoHealth 6:27-32

Bosch J, Martínez-Solano I (2006) Chytrids fungus infection related to unusual mortalities of Salamandra salamandra and Bufo bufo in the Penalara Natural Park, Spain. Oryx 40:84-89

Bosch J, Martínez-Solano I, García-París M (2001) Evidence of chytrid fungus infection involved in the decline of the common midwife toad (Alytes obstetricans) in protected areas of central Spain. Biol Conserv 97:331-337

> Bosch J, Carrascal LM, Duran L, Walker S, Fisher MC (2007) Climate change and outbreaks of amphibian chytridiomycosis in a montane area of central Spain; is there a link? Proc R Soc Lond B Biol Sci 274:253-260

Boyle DG, Boyle DB, Olsen V, Morgan JAT, Hyatt AD (2004) Rapid quantitative detection of chytridiomycosis (Batrachochytrium dendrobatidis) in amphibian samples using real-time Taqman PCR assay. Dis Aquat Org 60:141-148

Burrowes PA, Joglar RL, Green DE (2004) Potential causes for amphibian declines in Puerto Rico. Herpetologica 60: 141-154

Daszak P, Berger L, Cunningham AA, Hyatt AD, Green DE, Speare R (1999) Emerging infectious diseases and amphibian population declines. Emerg Infect Dis 5:735-748 > Daszak P, Cunningham AA, Hyatt AD (2003) Infectious dis- ease and amphibian population declines. Divers Distrib 9:141-150

Díaz-Paniagua C (1988) Temporal segregation in larval amphibian communities in temporary ponds at a locality in SW Spain. Amphibia-Reptilia 9:15-26

Díaz-Paniagua C, Gómez Rodríguez C, Portheault A, de Vries W (2005) Los anfibios de Doñana. Naturaleza y Parques Nacionales, Serie Técnica. Ministerio de Medio Ambiente, Madrid

Díaz-Paniagua C, Fernández-Zamudio R, Florencio M, García-Murillo P, Gómez-Rodríguez C, Siljestom P, Serrano L (2010) Temporary ponds from the Doñana National Park: a system of natural habitats for the preservation of aquatic flora and fauna. Limnetica 29:41-58

Duffus ALJ, Cunningham AA (2010) Major disease threats to European amphibians. Herpetol J 20:117-127

Fisher MC, Garner TWJ, Walker LA (2009a) Global emergence of Batrachochytrium dendrobatidis and amphibian chytridiomycosis in space, time and host. Annu Rev Microbiol 63:291-310

Fisher MC, Bosch J, Yin Z, Stead DA and others (2009b) Proteomic and phenotypic profiling of the amphibian pathogen Batrachochytrium dendrobatidis shows that genotype is linked to virulence. Mol Ecol 18:415-429

Garner TWJ, Walker S, Bosch J, Hyatt AD, Cunningham AA, Fisher MC (2005) Chytrid fungus in Europe. Emerg Infect Dis 11:1639-1641

> Garner TWJ, Walker S, Bosch J, Leech S, Rowcliffe M, Cunningham AA, Fisher MC (2009) Life history tradeoffs influence mortality associated with the amphibian pathogen Batrachochytrium dendrobatidis. Oikos 118: 783-791

> Harris RN, James TY, Lauer A, Simon MA, Patel A (2006) Amphibian pathogen Batrachochytrium dendrobatidis is inhibited by the cutaneous bacteria of amphibian species. EcoHealth 3:53-56

Hyatt AD, Boyle DG, Olsen V, Boyle DB and others (2007) Diagnostic assays and sampling protocols for the detection of Batrachochytrium dendrobatidis. Dis Aquat Org 73:175-192

> Johnson ML, Berger L, Philips L, Speare S (2003) Fungicidal effects of chemical disinfectants, UV light, desiccation and heat on the amphibian chytrid Batrachochytrium dendrobatidis. Dis Aquat Org 57:255-260

> Kriger KM, Hero JM (2006a) Survivorship in wild frogs infected with chytridiomycosis. EcoHealth 3:171-177

Kriger KM, Hero JM (2006b) Large-scale seasonal variation in the prevalence and severity of chytridiomycosis. J Zool 271:352-359

> Kriger KM, Hero JM (2007) The chytrid fungus Batrachochytrium dendrobatidis is non-randomly distributed across amphibian breeding habitats. Divers Distrib 13: $781-788$

Lips KR, Brem F, Brenes R, Reeve JD and others (2006) Emerging infectious disease and the loss of biodiversity in a neotropical amphibian community. Proc Natl Acad Sci USA 103:3165-3170

> Longcore J, Pessier A, Nichols D (1999) Batrachochytrium dendrobatidis gen. et sp. nov., a chytrid pathogenic to amphibians. Mycologia 91:219-227

> Longcore JR, Longcore JE, Pessier AP, Halteman WA (2007) Chytridiomycosis widespread in anurans of Northeastern United States. J Wildl Manag 71:435-444

Marantelli G, Berger L, Speare R, Keegan L (2004) Distribution of the amphibian chytrid Batrachochytrium dendro- 
batidis and keratin during tadpole development. Pac Conserv Biol 10:173-179

McDonald K, Alford RA (1999) A review of declining frogs in northern Queensland. In: Campbell A (ed) Declines and disappearances of Australian frogs. Environment Australia, Canberra, p 14-22

Nichols DK, Lamirande EW, Pessier AP, Longcore JE (2001) Experimental transmission of chytridiomycosis in dendrobatid frogs. J Wildl Dis 37:1-11

Rollins-Smith LA, Doersam JK, Longcore JE, Taylor SK, Shamblin JC, Carey C, Zasloff MA (2002) Antimicrobial peptide defenses against pathogens associated with global amphibian declines. Dev Comp Immunol 26: 63-72

Rollins-Smith LA, Woodhams DC, Reinert LK, Vredenburg VT, Briggs CJ, Nielsen PF, Conlon JM (2006) Antimicrobial peptide defenses of the mountain yellowlegged frog (Rana muscosa). Dev Comp Immunol 30: 831-842

Skerratt LF, Berger L, Speare R, Cashins S and others (2007) Spread of chytridiomycosis has caused the rapid global decline and extinction of frogs. EcoHealth 4:125-134

Stuart SN, Chanson JS, Cox NA, Young BE, Rodríques ASL, Fischman DL, Waller RW (2004) Status and trends of amphibian declines and extinctions worldwide. Science 306:1783-1786

Voyles J, Young S, Berger L, Campbell C and others (2009)

Editorial responsibility: Cynthia Carey,

Boulder, Colorado, USA
Pathogenesis of chytridiomycosis, a cause of catastrophic amphibian declines. Science 326:582-585

Woodhams DC, Alford RA (2005) Ecology of chytridiomycosis in rainforest stream frog assemblages of tropical Queensland. Conserv Biol 19:1449-1459

Woodhams DC, Voyles J, Lips KR, Carey C, Rollins-Smith LA (2006a) Predicted disease susceptibility in a Panamanian amphibian assemblage based on skin peptide defenses. J Wildl Dis 42:207-218

Woodhams DC, Rollins-Smith LA, Carey C, Reinert L, Tyler MJ, Alford RA (2006b) Population trends associated with skin peptide defenses against chytridiomycosis in Australian frogs. Oecologia 146:531-540

Woodhams DC, Rollins-Smith LA, Alford RA, Simon MA, Harris RN (2007a) Innate immune defenses of amphibian skin: antimicrobial peptides and more. Anim Conserv 10: 425-428

- Woodhams DC, Ardipradja K, Alford RA, Marantelli G, Reinert LK, Rollins-Smith LA (2007b) Resistance to chytridiomycosis varies among amphibian species and is correlated with skin peptide defenses. Anim Conserv 10: 409-417

- Woodhams DC, Vredenburg VT, Simon MA, Billheimer D and others $(2007 \mathrm{c})$ Symbiotic bacteria contribute to innate immune defenses of the threatened mountain yellow-legged frog, Rana muscosa. Biol Conserv 138: 390-398

Submitted: July 11, 2011; Accepted: October 18, 2011

Proofs received from author(s): February 26, 2012 